\title{
Production, Isolation, and Purification of L-Asparaginase from Pseudomonas Aeruginosa 50071 Using Solid-state Fermentation
}

\author{
Ashraf A. El-Bessoumy ${ }^{\dagger * *}$, Mohamed Sarhan and Jehan Mansour \\ 'Biochemistry Department, Faculty of Science, Alexandria University, Mohram Byk, Alexandria, Egypt \\ ${ }^{\ddagger}$ Botany Department, Faculty of Science, Zagazig University, Zagazig, Egypt
}

Received 27 March 2003, Accepted 24 July 2003

\begin{abstract}
The L-asparaginase (E. C. 3. 5. 1. 1) enzyme was purified to homogeneity from Pseudomonas aeruginosa 50071 cells that were grown on solid-state fermentation. Different purification steps (including ammonium sulfate fractionation followed by separation on Sephadex G-100 gel filtration and CM-Sephadex C50) were applied to the crude culture filtrate to obtain a pure enzyme preparation. The enzyme was purified 106-fold and showed a final specific activity of $1900 \mathrm{IU} / \mathrm{mg}$ with a $43 \%$ yield. Sodium dodecyl sulfate-polyacrylamide gel electrophoresis (SDSPAGE) of the purified enzyme revealed it was one peptide chain with $M_{r}$ of $160 \mathrm{kDa}$. A Lineweaver-Burk analysis showed a $K_{m}$ value of $0.147 \mathrm{mM}$ and $V_{\max }$ of 35.7 IU. The enzyme showed maximum activity at $\mathrm{pH} 9$ when incubated at $37^{\circ} \mathrm{C}$ for $30 \mathrm{~min}$. The amino acid composition of the purified enzyme was also determined.
\end{abstract}

Keywords: Amino acid composition, L-asparaginase, Production, Pseudomonas aeruginosa 50071, Purification

\section{Introduction}

L-Asparaginase (E. C. 3. 5. 1. 1) is present in many animal tissues, bacteria, plants, and in the serum of certain rodents, but not in mankind. L-Asparaginase is produced by a large number of microorganisms that include $E$. coli (Derst et al., 1994; Mercado \& Arenas, 1999), Erwinia cartovora (Maladkar et al., 1993; Aghaiypour et al., 2001), Enterobacter aerogenes (Mukherjee et al., 2000), Corynebacterium glutamicum (Juan et al., 1990), Candida utilis (Kil et al., 1995), Staphylococcus aureus (Muley et al., 1998), Thermus thermophilus (Prista \& Kyridio, 2001), and Pisum sativum

*To whom correspondence should be addressed.

Tel: 2-045-2213692; Fax: 2-03-3911794

E-mail: elbessoumy@ hotmail.com
(Siechiechowcicz \& Ireland, 1989). L-Asparaginase catalyzes the hydrolysis of L-asparagine into L-aspartate and ammonia. The precise mechanism of its action is still unknown although hydrolysis proceeds in two steps via a beta-acyl-enzyme intermediate (Fig. 1) (Hill et al., 1967). L-Asparaginase is produced throughout the world by submerged fermentation (SF). This technique has many disadvantages, such as the low concentration production, and consequent handling, reduction, and disposal of large volumes of water during the downstream processing. Therefore, the SF technique is a cost intensive, highly problematic, and poorly understood unit operation (Datar, 1986). Solid-state fermentation is a very effective technique as the yield of the product is many times higher when compared to that in SF (Arima, 1964), and it also offers many other advantages (Lonsane et al., 1985). Microbial asparaginases have been particularly studied for their applications as therapeutic agents in the treatment of certain types of human cancer (Gallogher et al., 1989). LAsparaginase from two bacterial sources (E. coli and Erwinia carotovora) is currently in clinical use for the treatment of acute lymphoblastic leukemia (Keating et al., 1993). It is also used for the treatment of pancreatic carcinoma (Yunis et al., 1977) and bovine lymphomosarcoma (Mosterson et al., 1988). A partially-purified L-asparaginase from Aspergillus terreus possesses antitumor property against Ehrlich's ascites

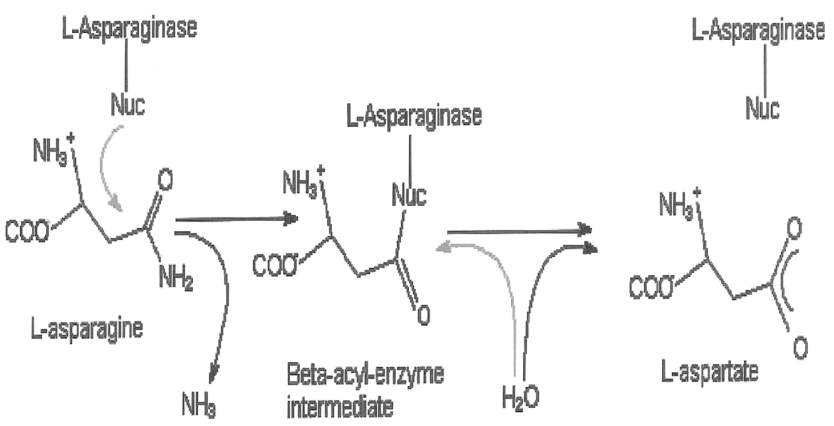

Fig. 1. Schematic illustration of the reaction mechanism of Lasparaginase. (Hill et al., 1967) 
in susceptible Swiss mice. From an observation of the toxicity and immunological responses, the enzyme may be non-toxic and have myelosuppressive/immunosuppressive (Ali et al., 1994). Therefore, the aim of the present work is the discovery of a new L-asparaginase producer that is serologically different from the previously reported ones, but one that has similar therapeutic effects.

\section{Materials and Methods}

Materials L-asparagine was kindly provided by Sigma (St. Louis, USA). Sephadex G-100, CM-Sephadex C50, and standard proteins for SDS-gel electrophoresis were purchased from Pharmacia, Uppsala, Sweden. All of the other chemicals were of analytical grade.

Microorganism media and growth conditions The Bacterial strain of Pseudomonas aeruginosa 50071 was kindly provided by the Microbiological Resource Center (MIRCEN), Ain Shams University, Cairo, Egypt. The stock culture was maintained on tryptic soy agar slants that contained tryptic casein Bios D (1.5\%), Soy peptone $(0.5 \%), \mathrm{NaCl}(0.5 \%)$, and agar Bios U $(1.5 \%)$. The culture was incubated at $37^{\circ} \mathrm{C}$ for $18 \mathrm{~h}$ and stored at $4^{\circ} \mathrm{C}$. Transfers from the single slant cultures at $48 \mathrm{~h}$ old were taken into $50 \mathrm{ml}$ aliquots of the defined inducible medium. These were placed in 250 $\mathrm{ml}$ Erlenmeyer flasks and used as the standard inocula ( $3 \mathrm{ml} / \mathrm{flask}$ ), unless otherwise indicated to initiate growth and give an initial OD at $A_{540}$ of 0.08 .

Cultivation was achieved by solid-state fermentation (SSF) as previously reported by Ramesh and Lonsane (1987). The medium that was used for the cultivation of Pseudomonas aeruginosa 50071 under (SSF) had the following composition: $10 \mathrm{~g}$ Soya bean meal of $0.4-0.8 \mathrm{~cm}$ particle size were moistened with $10 \mathrm{ml}$ of $0.01 \mathrm{M}$ phosphate buffer $\mathrm{pH} 7.4$, and placed in $250 \mathrm{ml}$ Erlenmeyer flasks. The fermentation media were sterilized by autoclaving for $15 \mathrm{~min}$ at a pressure of $15 \mathrm{Ib} /$ inch to raise the temperature to $121^{\circ} \mathrm{C}$. The flasks were inoculated with $3 \mathrm{ml}$ of the prepared bacterial suspension and incubated under static conditions at $37^{\circ} \mathrm{C}$ for $4 \mathrm{~d}$. The extracellular crude enzyme was prepared at the end of the fermentation period by the addition of $90 \mathrm{ml}$ of a $0.01 \mathrm{M}$ phosphate buffer $\mathrm{pH} 7$ to the fermented medium, shaking for $15 \mathrm{~min}$ followed by centrifugation at $8,000 \mathrm{rpm}$ for $20 \mathrm{~min}$. The cell free supernatant was used as the crude enzyme preparation.

Purification of L-asparaginase The purification was carried out at $4^{\circ} \mathrm{C}$ on the crude extract, according to the modified method of Distasio et al. (1976).

Ammonium sulfate fractionation Finely powdered ammonium sulfate was added to a $80 \%$ saturation. The mixture was left for 12 $\mathrm{h}$ at $4^{\circ} \mathrm{C}$, followed by centrifugation at $8,000 \mathrm{rpm}$ for $20 \mathrm{~min}$ at $4^{\circ} \mathrm{C}$. The precipitate was dissolved in a $0.01 \mathrm{M}$ phosphate buffer $\mathrm{pH} 8.5$ and dialyzed overnight against the same buffer at $4^{\circ} \mathrm{C}$.

Sephadex G-100 gel filtration The dialyzed ammonium sulfate fraction was applied to a Sephadex G-100 column that was preequilibrated with a $0.01 \mathrm{M}$ phosphate buffer $\mathrm{pH}$ 8.5. The protein elution was done with the same buffer at a flow rate of $5 \mathrm{ml} / \mathrm{min}$. The fractions were collected using a fraction collector (LKB Ultorace) at $4^{\circ} \mathrm{C}$. It was assayed for protein at $280 \mathrm{~nm}$ as well as for enzyme activity. The active fractions were pooled, dialyzed against the $0.01 \mathrm{M}$ phosphate buffer $\mathrm{pH} 8.5$, and concentrated.

CM-Sephadex C50 ion-exchange chromatography The concentrated enzyme solution was applied to the column of CMSephadex C50 that was pre-equilibrated with a $0.01 \mathrm{M}$ phosphate buffer, $\mathrm{pH}$ 8.5. It was eluted with the $\mathrm{NaCl}$ gradient $(0.1-0.5 \mathrm{M})$ and $0.1 \mathrm{M}$ borate buffer, $\mathrm{pH}$ 7. The active fractions were collected, dialyzed, concentrated, and lyophilized. This preparation was used in the subsequent step.

The enzyme was assayed by the direct nesslerization method according to the method of Sinha et al., (1991). One L-asparaginase unit (IU) is defined as the enzyme amount, which liberates $1 \mu \mathrm{mol}$ of the ammonia/min under optimal assay conditions. The protein concentration was determined by the modified Lowry's method (Kim et al., 2002).

Disc-PAGE A slab gel electrophoresis was carried out using a $15 \%$ polyacrylamide gel ( $\mathrm{pH} 7.8)$ with a $5 \%$ top gel $(\mathrm{pH} 6.2)$. After electrophoresis in a Tris-glycine buffer $(\mathrm{pH} 8.3)$ at $200 \mathrm{~V}$ for $7 \mathrm{~h}$ at $70^{\circ} \mathrm{C}$, the proteins in the gel were stained with Coomassie brilliant blue R-250 and destained (El-Gamal et al., 2001).

Molecular weight determination Sodium dodecyl sulfate polyacrylamide gel electrophoresis (SDS-PAGE) was carried out in a 3-mm slab gel of $6 \%$ acrylamide in a Tris-borate buffer $\mathrm{pH} 7.1$ containing $0.1 \%$ SDS. The gels were stained with 0.025 Coomassie brilliant blue R-250 and destained (Stegemann, 1979). The following standard proteins were used for the molecular weight determination under identical conditions: lysozyme (14 kDa), carbonic anhydrase $(31 \mathrm{kDa})$, ovalbumin $(42 \mathrm{kDa})$, bovine serum albumin $(67 \mathrm{kDa})$, and phosphorylase $(97 \mathrm{kDa})$.

Determination of amino acid composition This was carried out on the purified enzyme using a Beckman Amino Acid Analyzer (Model 119 GL), according to the method of Speckman et al., (1958).

\section{Results}

The partial purification of the L-asparaginase crude extract that was affected by the ammonium sulfate (80\%) precipitation showed that most of the enzyme activity was preserved in the precipitate. The total protein decreased from 4,150 to $674 \mathrm{mg}$ in the ammonium sulfate precipitation step. The specific activity increased to 497 and 1,900 IU/mg after the Sephadex G-100 and Sephadex C50 steps, respectively (Table 1).

Figure 2 shows the profile of the ammonium sulfate fraction purification on Sephadex G-100 gel filtration column chromatography. Although this fraction contained different protein molecules, only one peak showed activity for Lasparaginase. Also, the purification of the enzyme rich 
Table 1. Purification profile of L-asparaginase from Pseudomonas aeruginosa 50071

\begin{tabular}{cccccc}
\hline Step & $\begin{array}{c}\text { Collected } \\
\text { volume }(\mathrm{ml})\end{array}$ & $\begin{array}{c}\text { Total activity } \\
(\mathrm{IU})\end{array}$ & $\begin{array}{c}\text { Total Protein } \\
(\mathrm{mg})\end{array}$ & $\begin{array}{c}\text { Specific activity } \\
(\mathrm{IU} / \mathrm{mg})\end{array}$ & $\begin{array}{c}\text { Purification } \\
(\text { fold })\end{array}$ \\
\hline $\begin{array}{c}\text { Yield } \\
(\%)\end{array}$ & 74300 & 4150 & 17.9 & 0.00 \\
$\begin{array}{c}\left(\mathrm{NH}_{4}\right)_{2} \mathrm{SO}_{2} \\
\text { precipitation }\end{array}$ & 450 & 63100 & 674 & 93.7 & 5.2 \\
$\begin{array}{c}\text { Gel filtration on } \\
\text { Sephadex G100 column } \\
\text { CM-Sephadex } \\
\text { C50 column }\end{array}$ & 175 & 45200 & 91 & 497 & 27.7 \\
\hline
\end{tabular}

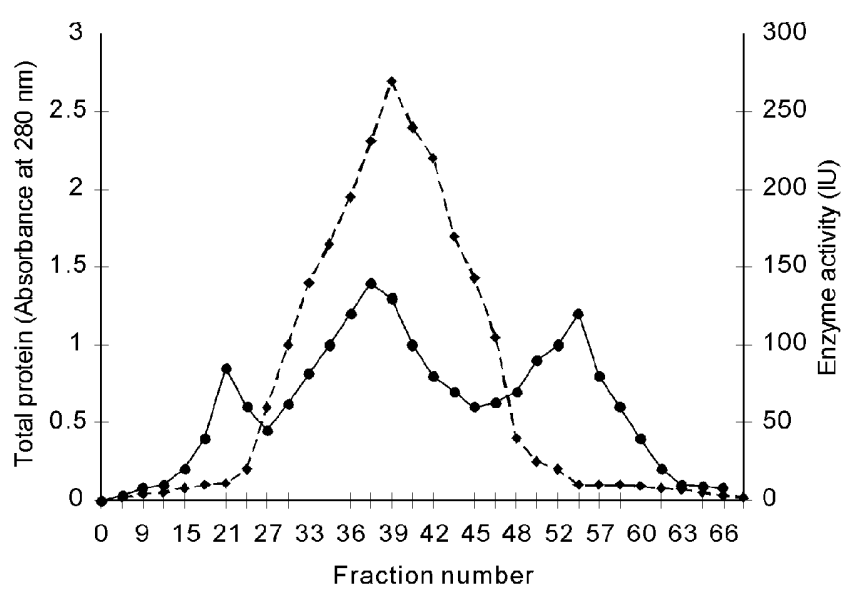

Fig. 2. First gel filtration chromatography of L-asparagiase. The dialyzed ammonium sulfate precipitate was chromatogrophed on Sephadex G-100. Total protein was monitored at $280 \mathrm{~nm}$. The fractions were assayed for the enzyme activity. (Dashed line, enzyme activity).

fractions of the Sephadex G-100 gel filtration on the CMSephadex C50 column is shown in Fig. 3. A sharp distinctive peak of L-asparaginase activity, which fits with only one protein peak, was obtained.

DISC-PAG of the enzyme preparation from different purification steps showed that the resolved electrophoretic bands were progressively improved from the crude extract to the final step of the CM-Sephadex C50 column. It revealed only one distinctive band that was indicated by the pure preparation of L-asparaginase (Fig. 4).

Molecular weight of L-asparaginase SDS-PAGE showed that the enzyme is one band with electrophoretic mobility of 0.48. By using different standard proteins with known molecular weights, it was discovered that the apparent molecular weight of Pseudomonas aeruginosa 50071 Lasparaginase was $160 \mathrm{kDa}$ (Fig. 5).

Kinetic properties of the purified L-asparaginase The $\mathrm{pH}$ influence on the L-asparaginase activity was studied using a $0.01 \mathrm{M}$ phosphate buffer of different $\mathrm{pH}$ values, ranging from 2.0 to 11 .The enzyme activity gradually increased until $\mathrm{pH} 9$,

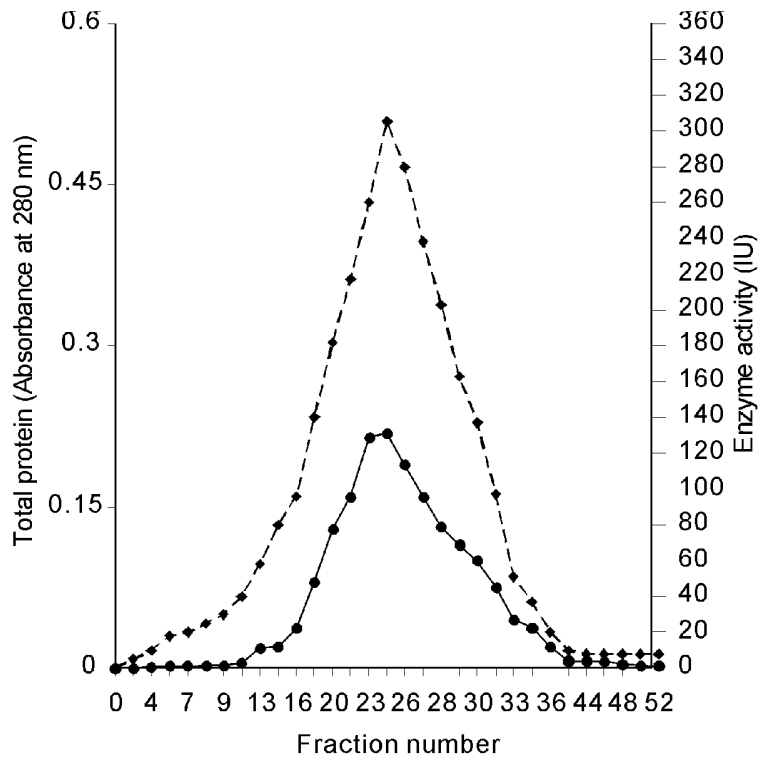

Fig. 3. Second CM-Sephadex C50 chromatography of Lasparaginase. The first gel filtration G-100 collected fraction was applied to CM-Sephadex C50. Total protein was monitored at $280 \mathrm{~nm}$ and the fractions was assayed for L-asparaginase activity. (Dashed line, enzyme activity).

at which time the maximum activity was observed. At higher $\mathrm{pH}$, the enzyme activity decreased (Fig. 6). The reaction rate of L-asparaginase was measured at various temperatures. Maximum activity was obtained at $37^{\circ} \mathrm{C}$. At higher temperatures, the reaction rate declined sharply.

The effect of the incubation time on L-asparaginase activity was studied in the ranges of zero to 50 min (Figs. 7 and 8). LAsparaginase activity increased as the incubation time increased. The activity ran at maximum for $30 \mathrm{~min}$ and decreased as the time increased. A Lineweaver-Burk analysis gave $K_{m}$ of $0.147 \mathrm{mM}$ and a $V_{\max }$ value of $35.7 \mathrm{IU}$ (Fig. 9).

Amino acid composition Table 2 shows the amino acid contents of the purified Pseudomonas aeruginosa $50071 \mathrm{~L}-$ asparaginase. The purified enzyme was rich in glycine and glutamic acid. 


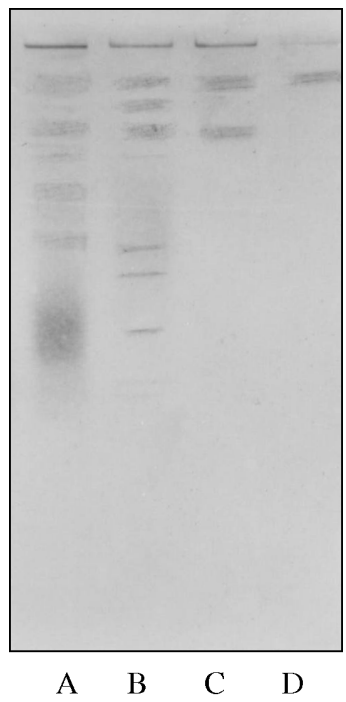

Fig. 4. Polyacrylamide gel electrophoresis of L-asparaginase from Pseudomonas aeruginosa 50071. Electrophresis of the enzyme was carried out on a $15 \%$ polyacrylamide gel in the absence of SDS and the gel was stained with Coomassei blue R-250. Lane A, crude extract; Lane B, ammonium sulfate fraction; Lane C, Sephadex G-100 gel filtration fraction; Lane D, CM-Sephadex C50 fraction.

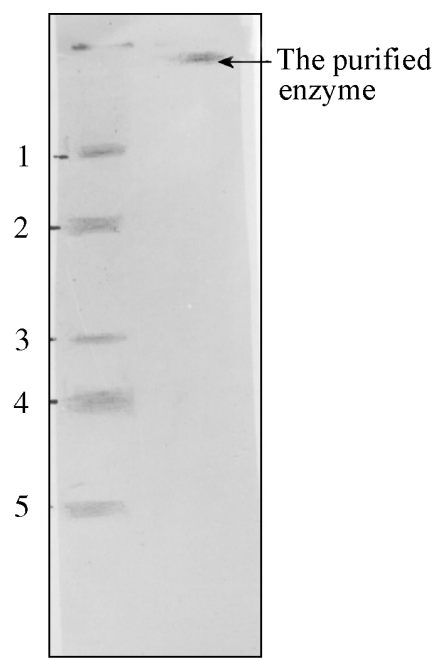

Fig. 5. PAGE-SDS of L-asparaginase from Pseudomonas aeruginosa 50071. Electrophresis was carried out on a $6 \%$ polyacrylamide containing $0.1 \%$ SDS. The gel was stained with Coomassie blue R-250. Lane A included the following standard proteins: 1. phosphorylase $\left(M_{r} 97 \mathrm{kDa}\right), 2$. bovine serum albumin $\left(M_{r} 67 \mathrm{kDa}\right), 3$. ovalbumin $\left(M_{r} 42 \mathrm{kDa}\right), 4$. carbonic anhydrase $\left(M_{r} 31 \mathrm{kDa}\right)$, 5. lysozyme $\left(M_{r} 14 \mathrm{KDa}\right)$. Lane B contained CMSephadex C50 column purified enzyme.

\section{Discussion}

Purification of Pseudomonas aeruginosa 50071 Lasparaginase was achieved by using $80 \%$ ammonium sulfate saturation, Sephadex G-100 gel filtration, and CM-Sephadex

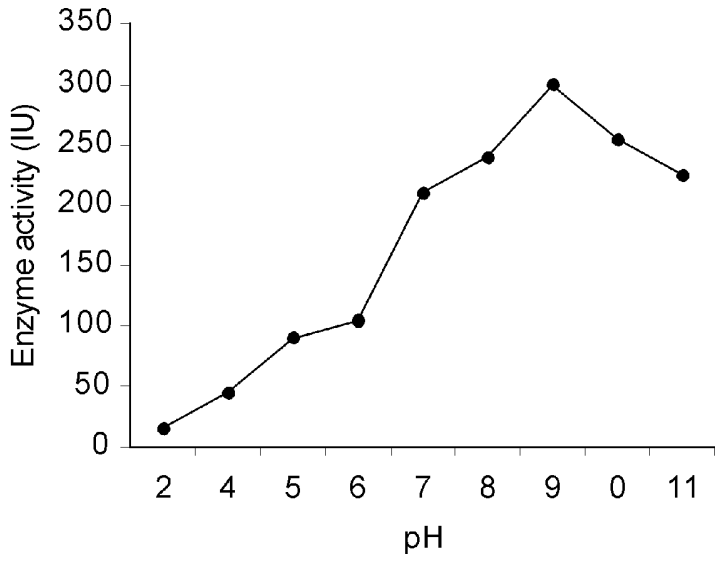

Fig. 6. Effect of $\mathrm{pH}$ on L-asparaginase activity. This was studied in the range value from 2-11 using $0.01 \mathrm{M}$ phosphate buffer.

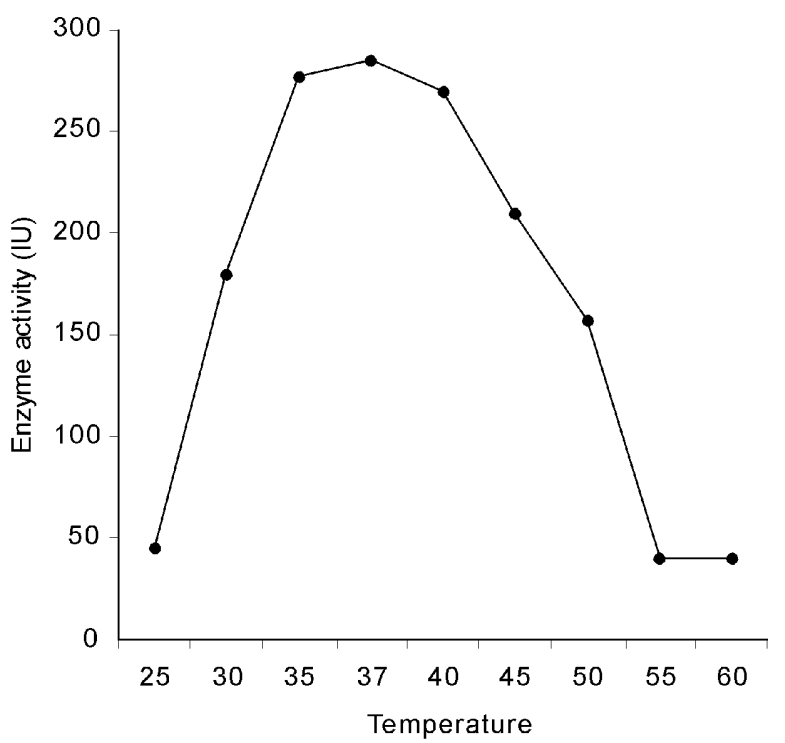

Fig. 7. Effect of temperature on L-asparaginase activity. This was studied in the range of $25-60^{\circ} \mathrm{C}$ in a $0.01 \mathrm{M}$ phosphate buffer, $\mathrm{pH} 9$.

C50 cation exchange column, respectively. The specific activity increased from 17.9 to $1900 \mathrm{IU} / \mathrm{mg}$ for the crude extract and the final preparation, respectively. The final preparation was examined using DISC-PAGE and SDSPAGE, which revealed that it contained one protein band with $M_{r}$ of $160 \mathrm{kDa}$. In this respect, the enzyme was more or less higher than that obtained from Corynebateriun glutamicum (Mesas et al., 1990) with $M_{r}$ of $80 \mathrm{kDa}$. Other bacterial species produced L-asparaginase of more than one component with variable molecular weights (Rozalska, 1989). Maximum L-asparaginase activity occurred when it was incubated with an optimum substrate concentration at $\mathrm{pH}$ 9. A similar $\mathrm{pH}$ value was obtained for E. coli (Castaman \& Rodeghiero, 1993 and Liboshi et al., 1999), Pseudomonas aeruginosa 10145 (Roberts et al., 1968), and many other microbial asparaginase activities (Balcao et al., 2001). A temperature profile showed 


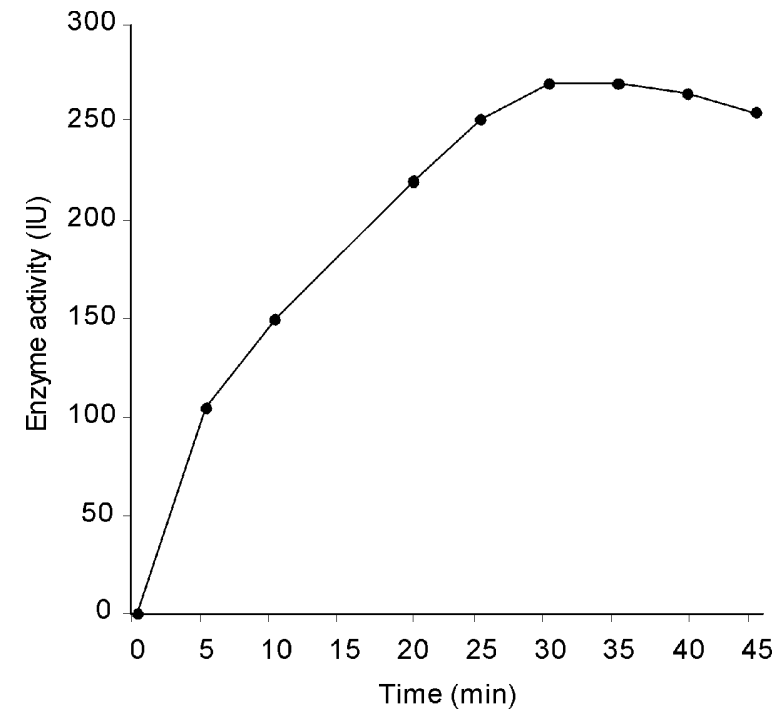

Fig. 8. Effect of incubation time on L-asparaginase activity. This was studied in the range value of 5 to $50 \mathrm{~min}$ at $37^{\circ} \mathrm{C}$ and $\mathrm{pH} 9$.

that the enzyme had maximum activity at $37^{\circ} \mathrm{C}$, and more than $52 \%$ activity was attained at $50^{\circ} \mathrm{C}$. Similar results were recorded for asparaginases from Pseudomonas stutzeri MB405 (Manna et al., 1995), E. carotovora (Maladkar et al., 1993), and Staphylococcus (Sobis \& Mikucki, 1991). Also, Qian et al., (1996) proved that E. coli L-asparaginase lost its activity more rapidly at higher temperatures. On the other hand, L-asparaginase from chrombacteriaceae had maximum activity at $20^{\circ} \mathrm{C}$ (Roberts et al., 1972). Incubation of Lasparaginase at $37^{\circ} \mathrm{C}$ for different times showed that the activity reached its maximum at $30 \mathrm{~min}$. Based on the Lineweaver-Burk analysis, the $K_{m}$ and $V_{\max }$ values of Lasparaginase from Pseudomonas aeruginosa 50071 were $0.147 \mathrm{mM}$ and $35.7 \mathrm{IU}$, respectively. This indicates the high affinity of the enzyme to the substrate. L-Asparaginase of different microorganisms has different substrate affinities and
Table 2. Amino acid contents (mole \%) of the purified Pseudomonas aeruginosa 50071 L-asparaginase

\begin{tabular}{cc}
\hline Amino acid & mol \% \\
\hline Aspartic acid & 8.70 \\
Threonine & 2.71 \\
Serine & 4.07 \\
Glutamic acid & 12.9 \\
Proline & 2.71 \\
Glycine & 17.1 \\
Alanine & 3.9 \\
Cystine & 1.64 \\
Valine & 2.1 \\
Methionine & 6.94 \\
Isoleucine & 1.97 \\
Leucine & 4.25 \\
Tyrosine & 1.72 \\
Phenylalanine & 3.07 \\
Histidine & 3.99 \\
Lysine & 5.07 \\
Arginine & 3.32 \\
\hline
\end{tabular}

probably plays different physiological roles in the enzyme activity. Higher $K_{m}$ values $(2.5 \mathrm{mM}$ and $3.5 \mathrm{mM})$ for Lasparaginase from $C$. glueamicum and E. coli, respectively, have been reported (Willis and Woolfolk, 1974). On the other hand, a lower $K_{m}$ value $(0.074 \mathrm{mM})$ was obtained for Lasparaginase from Vibrio succinogenes (Willis and Woolfolk, 1974).

The quaity of $P$. aeruginosa 50071 L-asparaginase was assessed for its amino acid contents. The purified enzyme was rich in glycine and glutamic acid. Relatively higher amounts of aspartic acid, methionine, lysine, leucine, and serine were present. Qian et al. (1996) reported that aspartic acid protects the active site of E. coli L-asparaginase. Finally, this work gives promising results on the possible production of L-

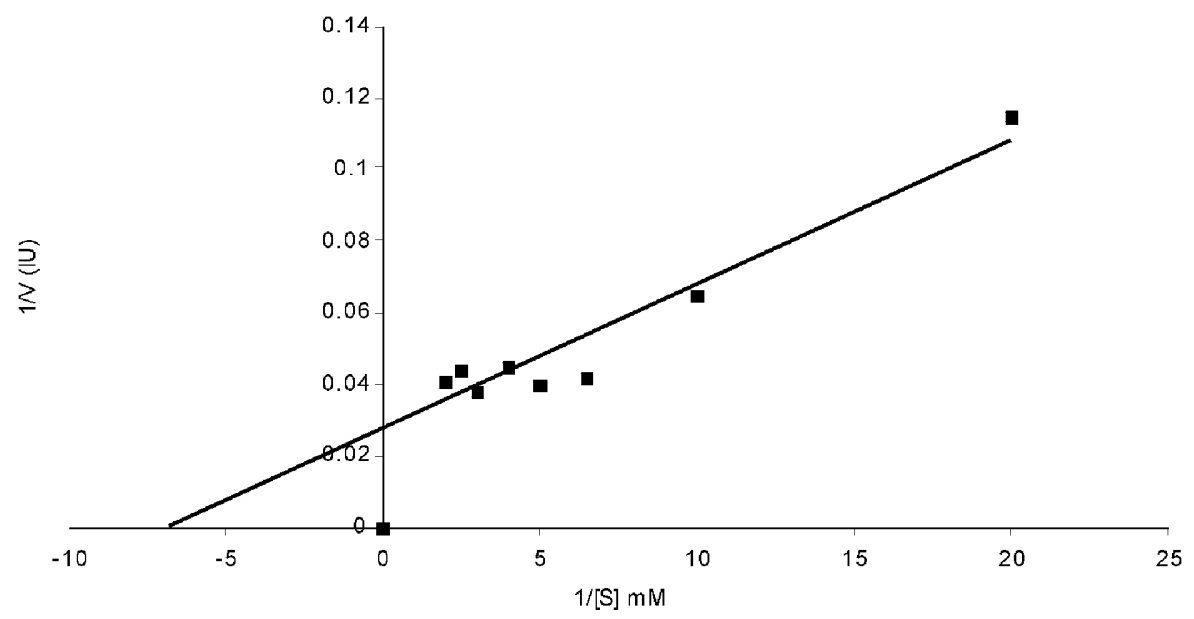

Fig. 9. Determination of $K_{m}$ and $V_{\max }$ of L-asparaginase from Pseudomonas aeruginosa 50071. A Lineweaver-Burk plot was used to detect the dependence of L-asparaginase activity on the L-asparagine concentration. 
asparaginase from Pseudomonas aeruginosa 50071 under solid-state fermentation. This is reported here for the first time. Economically, this enzyme could be produced from cheap, untreated biomass residues. The excellent properties of this enzyme, such as the activity at the alkaline $\mathrm{pH}$ range at $37^{\circ} \mathrm{C}$, make it extremely valuable in the chemotherapeutic treatment of leukemia.

\section{References}

Aghaiypour, K., Wlodowes, A. and Lubkowski, J. (2001) Structural basis for the activity and substrate specificity of Erwinia chrysanthemi L-asparaginase. Biochem. 40, 5655-5664.

Ali, S. S., Rai, V., Soni, K., Kulshrestha, P. and Lai, S. K. (1994) A fungal Lasparaginase with potential antitumor activity. Ind. $J$. Microbiol. 34, 73-76.

Arima, K. (1964) Microbial enzyme production in Global Impact of Applied Microbiology, M.P. Starr (eds.), pp. 279-299, John Willey, New York, USA.

Balcao, V. M., Mateo, C., Fernandez, L., Lafuente, R., Malcota, F. X. and Guisan, J. M. (2001) Structural and functional stabilization of L-asparaginase via subunit: Immobilization on to highly activated supports. Biotechnol. Prog. 17, 537-542.

Castaman, G. and Rodeghiero, F. (1993) Erwinia and E. coli derived L-asparaginase have similar effect on hemostasis. Hematologica. 78, 57-60.

Datar, R. (1986) Economic of primary separation steps in relation to fermentation and genetics engineering. Process Biochem. 21, 19-26.

Derst, C., Wehner, A., Specht, V. and Rohm, K. H. (1994) States and functions of tyrosine residues in Escherichia coli asparaginase. Eur. J. Biochem. 224, 533-540.

Distasio, J. A., Nredrerman, R. A., Kafkewitz, D. and Goodman, D. (1976) Purification and characterization of L-asparaginase with antilymphoma activity from Vibroi succinogenes. J. Biolog. Chem. 251, 6929-6933.

El-Gamal, B., Temsah, S., Olama, Z., Mohamed, A. and El-Sayed, M. (2001) Purification and characterization of chloramphenicol acetyltransferase from Morganella morganii. J. Biochem. Mol. Biol. 34, 415-420.

Gallogher, M. P., Murshall, R. D. and Wilson, R. (1989) Asparaginase drug for treatment of acute lymphoblastic leukemia. Essays Biochem. 24, 1-40.

Hill, J., Roberts, J., Loeb, E., Kahn, A. and Hill, R. (1967) Lasparaginase therapy for leukemia and other malignant neoplasm. JAMA 202, 882.

Keating, M. J., Holmes, R, and Lerner, S. H. (1993) Lasparaginase and PEG asparaginase past, present and future. Leuk. Lympmoma. 10, 153-157.

Kil, J. O., Kim, G. N. and Park, I. (1995) Extraction of extracellular L-asparaginase from Candida utilis. Biosc. Biotechnol. Biochem. 59, 749-750.

Kim, S. K., Park, P. J., Kim, J. B. and Shahidi, F. (2002) Purification and characterization of a collagenolytic protease from the filefish, Novoden modestrus. J. Biochem. Mol. Biol. 35, 165-171.

Liboshi, Y., Papst, P. J., Hunger, S. P. and Terada, N. (1999) Lasparaginase inhibits the rapamycine-targeted signaling pathway. Biochem. Biophys. Res. Commun. 260, 534-539.

Lonsane, B. K., Ghildyal, N. P., Budiatman, S. and Ramakrishnan, S. V. (1985) Engineering aspects of solid-state fermentation. Enzyme Microb. Technol. 7, 228-256.

Maladkar, N. K., Singh, V. K. and Naik, S. R. (1993) Fermentative production and isolation of L-asparaginase from Erwinia cartovora EC-113. Hidustan Antibiot. Bull. 35, 77-86.

Manna, S., Sinha, A., Sadhukhan, R. and Chakrabaty, S. L. (1995) Purification, characterization and antitumor activity of Lasparaginase isolated from Pseudomonas stutzeri MB-405. Curr. Microbiol. 30, 291-298.

Mercado, L. and Arenas, G. (1999) Escherichia coli L-asparaginas induced phosphorylation of endogenous polypeptide in human immune cells. Sangre (Brac), 44, 438-442.

Mesas, J. M., Gill, J. A. and Martin, J. F. (1990) Characterization and partial purification of L-asparaginase from Corynebacterium glutamicum. J. Gen. Microbiol. 136, 515-519.

Mosterson, M. A., Hull, B. L. and Vollmer, L. A. (1988) Treatment of bovine lymphomsarcoma with L-asparaginase. $J$. American Vet. Med. assoc. 192, 1301-1306.

Mukherjee, J., Majumadar, S. and Scheper, T. (2000) Studies on nutritional and oxygen requirements for production of $\mathrm{L}$ asparaginase by Enterobacter aerogenes. Appl. Microbial Biotechnnol. 53, 180-184.

Muley, R. G., Sarker, S., Ambedkar, S. and Nail, S. R. (1998) Influence of alkali treated corn steep liquor containing medium on protein production by Staphylococcus aureus. Folia Microbiology, 43, 31-34.

Prista, A. A. and Kyridio, D. A. (2001) L-asparaginase of thermothermophilus: purification, properties and identification of essential amino acids for catalytic activity. Mol. Cell. Biochem. 216, 93-101.

Qian, G., Zhou, J., Wang, D. and Hie, B. (1996) The chemical modification of E. coli: L-asparaginase by N,O-Carboxy methyl chitosan cells, blood substituents and immobilization. Biotechnol. 24, 567-577.

Ramesh, M. V. and Lonsane, B. K. (1987) Solid-state fermentation for production of amylase by Bacillus megaterium $16 \mathrm{M}$. Biotechnol. Lett. 51, 323-328.

Roberts, J., Holcenberg, I. S. and Dolwy, W. C. (1972) Crystallization and properties of Achromobacteriacae glutaminase, asparaginase with antitumor activity. J. Biolog. Chem. 247, 84-90.

Roberts, J., Prager, M. and Bachynsky, N. (1968) New procedures for purification of L-asparaginase with high yield from $E$. coli. J. Bacteriol. 95, 2117-2123.

Rozalska, M. (1989) Staphylococcal L-asparaginase: Purification and properties of enzymatic protein. Acta. Microbiol. Pol. 38, 233-245.

Siechiechowcicz, K. and Ireland, R. (1989) Isolation and properties of an asparaginase from leaves of Pisum sativum. Phytochem. 28, 2275.

Sinha, A., Manna, S., Roy, S. K. and Chakrabaty, S. L. (1991) Induction of L-asparaginase synthesis in Vibrio proteus. Indian J. Medical Res. 93, 289-292.

Sobis, M. and Mikucki, J. (1991) Staphylococcal L-asparaginase: Enzyme kinetics. Acta Microbiol. Pol. 40, 143-152.

Spekman, D. H., Moore, S. and Steins W. (1958) Chromatography of amino acids on sulphonated polystyrene resins. Anal. Chem. 30, 1185-1190. 
Stegemann, H. (1979) Properties and physiological changes in storage protein in Chem. and Biochem. of Plant Protein, Horborn, J. B. and Van Sumez (ed.), Academic Press, London, UK.

Willis, R. C. and Woolfolk, R. (1974) Asparagine utilization in E. coli. J. Bacteriol. 118, 231-241.

Yunis, A. A., Arimures, G. K. and Russin, D. J. (1977) Humane pancreatic carcinoma (MIA $\mathrm{PaCa}-2$ ) in continues culture sensitivity to asparaginase. Int. J. Cancer. 19, 218-235. 